\title{
Influence of temperature on the performance of anaerobic treatment systems of municipal wastewater
}

\author{
Silvânia Lucas dos Santos ${ }^{1}$, Sílvia Raphaele Morais Chaves ${ }^{1}$ and Adrianus van Haandel \\ ${ }^{1}$ Federal University of Campina Grande Av Aprígio Veloso 882, Campina Grande, Brazil
}

\begin{abstract}
Anaerobic sewage treatment systems, especially upflow anaerobic sludge blanket (UASB) reactors, have found wide application over the past decades, particularly in regions with a warm climate. A low sewage temperature is generally considered as a factor contributing to poor performance, characterized by an increase of the COD fractions in the effluent and the generated sludge, and decreasing the fraction that is transformed into methane. An experimental investigation was carried out at pilot scale to establish the values of the three COD fractions for different values of temperature and the applied organic load. The sludge age of the anaerobic treatment, together with temperature, was identified as the main operational variable that affects the efficiency of anaerobic treatment. An empirical expression was derived for the values of the three factions as a function of these two variables. From the results of the experimental investigation it was apparent that there is no point in applying a sludge age of more than $100 \mathrm{~d}$, when the reactor is near its best performance. An expression was derived to establish the hydraulic retention time for maximum digestion efficiency as a function of temperature, concentration and composition of organic material and sludge mass. It was established that the main limit to the sludge hold-up in UASB reactors treating sewage is not the sludge settleability, but rather the break-up of flocs leading to loss of small, poorly-settling particles.
\end{abstract}

Keywords: anaerobic sewage treatment, UASB reactor, temperature, sludge age, process simulation

\section{INTRODUCTION}

In anaerobic digestion organic material in wastewaters is transformed into biogas due to four sequential processes (Gujer and Zehnder, 1983): (i) hydrolysis, the solubilisation of particulate organic material or macromolecules generating soluble materials like sugars, amino acids and lipids; (ii) the fermentation of the soluble material to secondary metabolites of smaller molecular weight (volatile acids, alcohols etc.); (iii) the fermentation of these metabolites to acetate and hydrogen, the substrates of the fourth process; and (iv) methane production, accompanied by variable production of carbon dioxide and other gases. Thus anaerobic digestion leads to the establishment of four distinct microbial populations, the first three ones being bacteria and the fourth archaea.

The rates of each of these four biological processes is strongly influenced by temperature. The transformation rates increase with rising temperature until a maximum is reached at about $35-37^{\circ} \mathrm{C}$, the optimal temperature (Luostarinen et al., 2007). In concentrated wastewaters or solid wastes, the produced methane can be used to increase the temperature to the optimal value, even at low environmental temperatures. In more dilute wastewaters like sewage the energy content of the organic material is insufficient to effect a meaningful increase in temperature (Van Haandel and Lettinga, 1994). Hence, if anaerobic treatment is to be applied, these wastewaters must be digested at the temperature at which they are generated, which is lower than the optimal value.

It is important to stress that the four basic processes of anaerobic digestion are sequential: if the first process, hydrolysis, is incomplete, the substrate production for the second process will be smaller and so on. Indeed hydrolysis

\footnotetext{
* To whom all correspondence should be addressed. e-mail: adrianusvh@gmail.com Received 29 April 2016; accepted in revised form 12 March 2018
}

has been identified by many research workers as the ratelimiting process, especially at low temperatures (Aiyuk et al., 2006; Verstraete et al., 1997). Also, it is important to recognize that the digestion must be complete, i.e., include methanogenisis, to effect the removal of organic material from the liquid phase.

In anaerobic digesters the influent COD is divided into three fractions that can be determined independently: (i) a fraction in the effluent of the anaerobic system, (ii) a fraction converted into sludge, and (iii) a fraction transformed into methane and present in biogas. A decrease in temperature reduces the rate of all biological processes and therefore has an observable effect on the division of the organic material in the reactor: the fractions in the effluent and converted into sludge will increase at the expense of the digested fraction. The lower digestion efficiency and biogas production has an undesirable indirect effect: fewer gas bubbles will cause less mixing of the reactor, which may have an adverse effect on the intensity of contact between substrate and biological sludge, a prerequisite for efficient treatment (Lettinga et al., 1993).

At decreasing temperature, the lower fraction of digested COD is directly related to a higher effluent fraction. The higher fraction of COD converted into sludge has an even more undesirable effect: due to the lower hydrolysis rate an increasing part of the influent particulate material will not be hydrolysed, but instead will flocculate and become part of the sludge. Thus, there is an increase in sludge production and, since the sludge hold-up is fixed, the sludge age will decrease. In an earlier paper (Santos et al., 2016) the importance of a long sludge age for efficient anaerobic treatment of sewage was shown. The sludge age of a system is long when the sludge mass retained in the reactor is large or when the sludge production rate is low. The maximum sludge retention basically depends on the reactor volume and on the efficiency of the sludge retention device, as well as on the sludge settleability. Sludge production increases with decreasing temperature, as hydrolysis becomes less efficient. Reduction of the sludge age when temperature 
decreases has been reported by many researchers (Chong et al., 2012; Lew et al., 2011; Van Lier et al., 2008).

Temperature also has an effect on the produced biogas: at lower temperatures methane solubility in water increases and the release of biogas is reduced. While this is irrelevant for concentrated wastewaters, for sewage at low temperatures the dissolved fraction may represent up to $50 \%$ of the produced quantity (Chernicharo, 2015). Dissolved methane in the effluent is undesirable because it reduces the biogas production and the dissolved methane fatally will end up in the atmosphere, contributing to greenhouse gas release. Thus, decrease of temperature has several undesirable effects: (i) deterioration of the effluent quality, (ii) increase of sludge production with increased instability, (iii) decrease of biogas production (iv), lower mixing intensity as sludge production increases, (v) decrease of the sludge age, and (vi) increased fraction of produced methane dissolved in the effluent.

Anaerobic digestion can still be efficient at lower than optimal temperatures, but due to the lower conversion rates a larger reactor is needed. Thus, when evaluating the feasibility of anaerobic digestion at lower than optimal temperatures, the inherent advantages of anaerobic digestion must be weighed against the increasing costs of the reactor and at some temperature it will be considered that other treatment options of dilute wastewaters are preferable, like, for example, activated sludge.

The aim of this paper is to develop a relationship between the anaerobic digestion efficiency and the two most important operational variables: temperature and sludge age. An empirical expression is developed that will estimate the digestion efficiency for any temperature and sludge age. The temperature in most cases is known, but the maximum sludge age can only be determined when the reactor is already in operation. In practice the average sludge concentration in a UASB reactor will typically be between 20 and 30 gTSS/L. In this paper it will be shown how the reactor volume is related to the sludge age for the minimum and the maximum range of sludge concentrations, that is, an expression is developed for the required reactor volume and retention time of a UASB reactor for any particular temperature.

\section{MATERIALS AND METHODS}

An experimental investigation was carried out at pilot scale at the research site of the Federal University of Campina Grande in Campina Grande, where the sewage temperature is $25 \pm 1^{\circ} \mathrm{C}$, throughout the year. Raw sewage was pumped daily from the main outfall that runs through the terrain of the lab into a stirred tank from which dosing pumps fed four UASB reactors which were operated at different temperatures: 25, 20, 15 and $12^{\circ} \mathrm{C}$. The samples for the influent composition were taken from the dosing pump flows. Influent and effluent samples were kept in the refrigerator until tests were carried out hours later. The experimental system is shown in Fig. 1. Cold water was generated by conventional cooling equipment (freezer) and
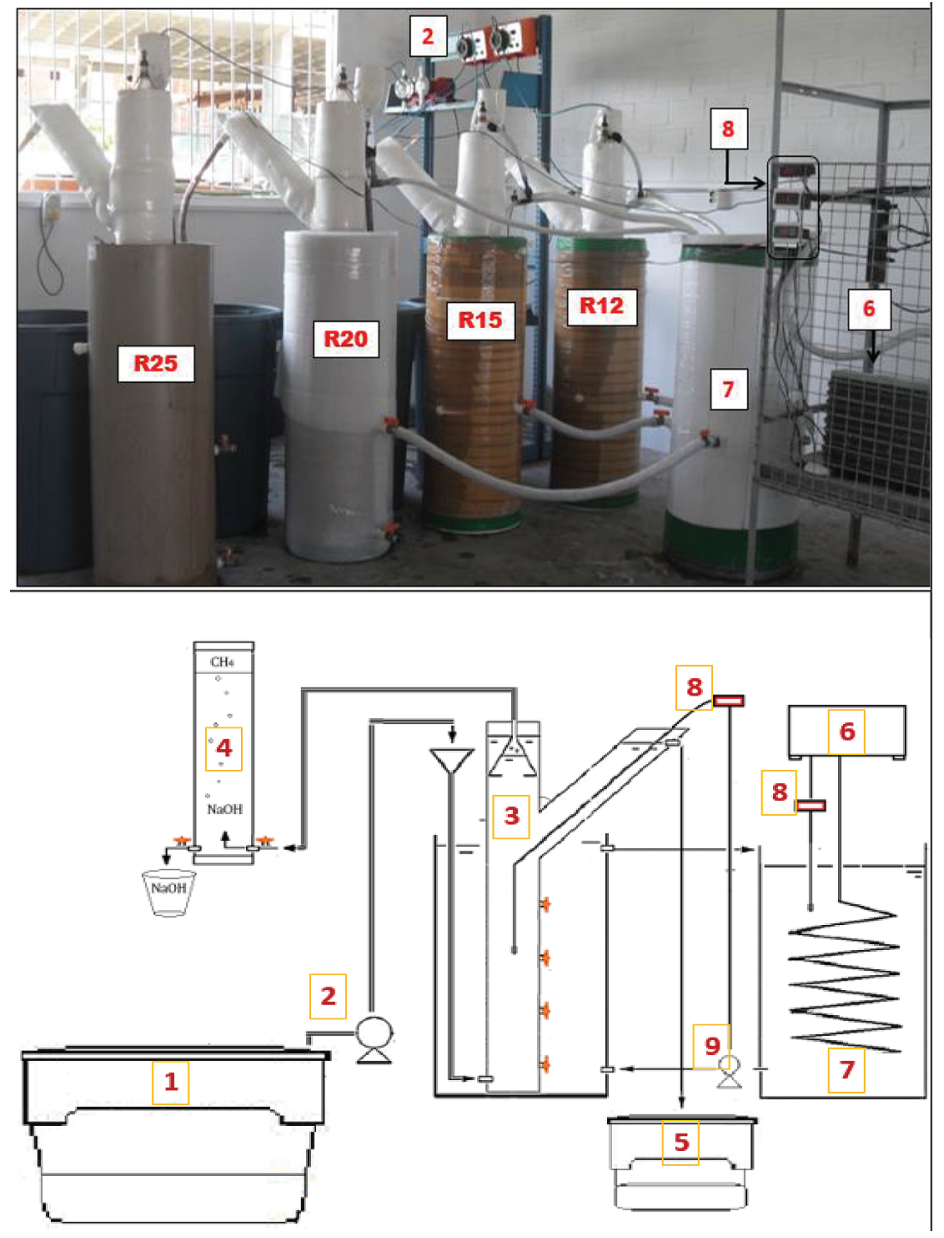

Legend

R25-UASB reactor tank with $25^{\circ} \mathrm{C}$; $\mathrm{R} 20$ - UASB reactor tank with $20^{\circ} \mathrm{C}$; R15-UASB reactor tank with $15^{\circ} \mathrm{C}$; R12 - UASB reactor tank with $12^{\circ} \mathrm{C}$; 1 -Raw sewage tank; 2 -Dosing pumps;

3 -UASB (two-two phase separators);

4 -Mariotti flasks:

5 -Reactor effluent tank;

6-Cooling equipment (freezer);

7 -Central cold water tank;

8 -Electronic temperature controller with sensor

9 - Recycle pump.

Figure 1

Flow sheet and photo of the experimental system used in the investigation 
used to control the temperatures at the desired values for each of the four reactors by recycling from the cold-water tank to each of the tanks in which the reactors were placed whenever the temperature rose above the control value. Thus, a constant flow of sewage was introduced by dosing pumps, while the reactors were functioned at the controlled temperatures.

In Fig. 2, a sketch of the used UASB reactors is shown with their basic dimensions. The reactors had a total useful volume of about $25 \mathrm{~L}$, a height of $1.35 \mathrm{~m}$ and a diameter of $0.15 \mathrm{~m}$. The reactors were made from ordinary PVC tubes and immersed in cylindrical PVC tanks with a diameter of $0.3 \mathrm{~m}$. The conventional three-phase separator of UASB reactors was substituted by two two-phase separators: gas/solid and liquid/ solid. This configuration was earlier shown to give excellent results with a higher digestion efficiency than conventional UASB reactors with one three-phase separator, applying the same volume and loading rates. This was attributed to the more efficient solid-liquid separator (Coelho et al., 2003).

The reactors were inoculated with sludge from anaerobic sewage treatment units and operated at the different temperatures until steady-state conditions were established, after which experimental data were obtained to characterize the performance of the reactors. During the entire experimental investigation no sludge was intentionally wasted, but sludge was expelled from the reactors, when these were 'full' of sludge. The sludge production rate in the reactors was equated to the rate of sludge expulsion. The sludge expulsion was used to determine the sludge production as follows: when the reactor was operating under steady-state conditions, a sample of effluent was collected and its COD concentration was determined.

Then a $1 \mathrm{~L}$ sample was transferred to an Imhoff cone, where the solids were allowed to settle for $30 \mathrm{~min}$, and the settled COD was determined from the clarified supernatant. The COD of the decanted sample was taken to be the effluent COD and the difference between the raw and decanted was the COD converted into sludge. The COD converted into biogas was calculated as the difference between the influent COD and the COD of the raw effluent. The sludge mass of the reactors was determined from the average concentration after discharging the reactor contents into buckets and mixing. Samples of the mixed sludge were also used to determine the main mechanical and biological properties: the settleability, which determines to a large extent the mass of the sludge that can be kept in the reactor and the specific methanogenic activity which determines the methane production potential per unit mass of sludge and per time unit.

The settleability and methanogenic activity of the sludge expelled from the reactors was also determined. Sludge settleability was determined by evaluating the constants of Vesilind's equation (1967), that links the settling velocity to the sludge concentration:

$$
v=v_{o} e^{(-k X t)}
$$

where:

$v=$ sludge settling velocity

$X_{\mathrm{t}}=$ sludge concentration

$v_{\mathrm{o}}, k=$ Vesilind's settleability constants

Leitão (2004) proposed the dynamic test to determine the Vesilind constants $\left(v_{\mathrm{o}}\right.$ and $k$ ). In this test a sludge sample with a known amount of solids is placed in a transparent vertical tube with a known diameter, after which a constant flow of water (or effluent) is applied in upward direction. The sludge in the tube will expand until the settling velocity (Eq. 1) is

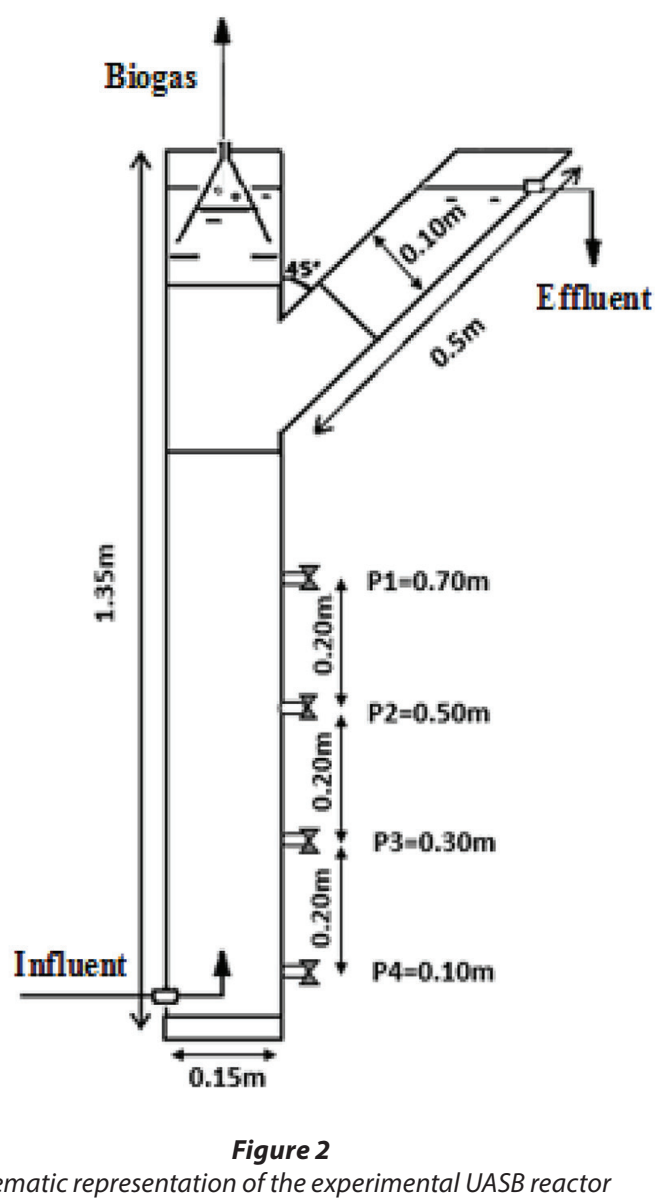

equal to the rising velocity of the liquid, resulting in a constant interface between sludge and clarified supernatant. Then the liquid velocity is calculated from the flow rate and the tube area and the sludge concentration from the sludge mass and the expanded volume. By applying this procedure for various flow rates, an empirical relationship can be established between the settling rate $(v)$ and the sludge concentration $\left(X_{t}\right)$. By plotting the experimental points $v$ and $X_{t}$ on semi-log paper the constants of in Eq. 1 can be determined.

The specific methanogenic activity (SMA) is determined by measuring the maximum volume of methane that can be produced by a sludge sample placed in a special flask used for this purpose. It is normally expressed as the mass of COD that is transformed into methane per unit mass of sludge and per time unit under ideal operational conditions, recognizing that $1 \mathrm{~g}$ of methane COD has a volume of approximately $375 \mathrm{~mL}$ at the optimal temperature of $35^{\circ} \mathrm{C}$ (Van Haandel and Lettinga, 1994). The optimal operational conditions include nature and concentration of substrate, presence of macro- and micro-nutrients, $\mathrm{pH}$ and temperature, as well as the absence of light. In this paper acetate was used as the only organic substrate, so that the results reflect the acetogenic activity and not the total (including hydrogenotrophic activity) value. The methanogenic activity of the sludges was determined at the temperatures of the reactors.

\section{RESULTS AND DISCUSSION}

The four reactors operated at different temperatures were all fed with constant flows, so that steady-state conditions were established. During the experimental investigation several 
flow rates were applied for periods long enough to establish steady state, so that characteristic conditions were established for each of the different hydraulic retention times. Table 1 shows the average values of COD concentrations in the reactor operated at $25^{\circ} \mathrm{C}$ for the influent, as well as the raw and settled effluent for the different retention times that were used. These data were then used to calculate two important variables: (i) the fractions of the influent COD that were in each of the three options available to the organic material: (a) discharge in the effluent; or (b) discharge as sludge; or (c) discharge as methane, (ii) the sludge age.

The COD fraction discharged in the effluent is determined experimentally as the ratio between the average COD in the settled effluent and the influent:

$$
f_{\mathrm{s}}^{\prime}=S_{\mathrm{es}} / S_{\mathrm{ti}}
$$

where:

$f_{\mathrm{s}}^{\prime}=$ fraction of soluble COD in the effluent

$S_{\mathrm{es}}=$ settled effluent COD

$S_{\mathrm{ti}}^{\mathrm{es}}=$ influent COD

Similarly, the fraction of the influent COD that was converted into sludge was calculated as the ratio between the difference between the raw and settled effluent COD and the influent COD:

where:

$$
f_{\mathrm{x}}^{\prime}=\left(S_{\mathrm{ex}}-S_{\mathrm{es}}\right) / S_{\mathrm{ti}}
$$

$f_{\mathrm{x}}^{\prime}=$ fraction of COD leaving the reactor as settleable material (sludge)

$S_{\text {ex }}=$ raw effluent COD

The values in the settled effluent $\left(f_{\mathrm{s}}^{\prime}\right)$ and converted into sludge $\left(f_{\mathrm{x}}^{\prime}\right)$ are calculated from the experimental data of the COD fractions and are shown in Table $2\left(3^{\text {rd }}\right.$ column) for different retention times.
The sludge mass in the reactors was determined by emptying the reactor and taking a well-mixed sample for total and volatile suspended solids tests. The results of these tests are also presented in Table 2. The sludge age (also in Table 2)

\section{TABLE 2}

Calculated values of the COD fractions in the effluent and converted into sludge as well as the sludge age for the different retention times. The total and volatile sludge masses are also indicated

\begin{tabular}{|l|c|c|c|c|c|}
\hline $\begin{array}{l}\text { Retention } \\
\text { time (h) }\end{array}$ & Parameter & $\mathrm{T}=25^{\circ} \mathrm{C}$ & $\mathrm{T}=20^{\circ} \mathrm{C}$ & $\mathrm{T}=15^{\circ} \mathrm{C}$ & $\mathrm{T}=12^{\circ} \mathrm{C}$ \\
\hline \multirow{5}{*}{8} & $f_{\mathrm{s}}$ & & & 0.30 & 0.35 \\
& $f_{\mathrm{x}}^{\prime}$ & & & 0.10 & 0.08 \\
& $X_{\mathrm{t}}$ & - & - & 24.5 & 26.2 \\
& $X_{\mathrm{v}}$ & & & 15.8 & 16.7 \\
& $R_{\mathrm{s}}$ & & & 192 & 154 \\
\hline \multirow{5}{*}{6} & $f_{\mathrm{s}}^{\prime}$ & 0.22 & 0.28 & 0.34 & 0.38 \\
& $f_{\mathrm{x}}^{\prime}$ & 0.07 & 0.10 & 0.08 & 0.15 \\
& $X_{\mathrm{t}}$ & 29.6 & 30.1 & 27.1 & 26 \\
& $X_{\mathrm{v}}$ & 18.7 & 19.4 & 17.6 & 16.4 \\
& $R_{\mathrm{s}}$ & 146 & 104 & 131 & 60 \\
\hline \multirow{5}{*}{3} & $f_{\mathrm{s}}^{\prime}$ & 0.22 & 0.29 & 0.48 & 0.51 \\
& $f_{\mathrm{x}}^{\prime}$ & 0.13 & 0.10 & 0.25 & 0.27 \\
& $X_{\mathrm{t}}$ & 29.1 & 19.6 & 23 & 25.1 \\
& $X_{\mathrm{v}}$ & 18.7 & 12.4 & 17.9 & 18.8 \\
& $R_{\mathrm{s}}$ & 52 & 45 & 24 & 23 \\
\hline \multirow{5}{*}{3} & $f_{\mathrm{s}}^{\prime}$ & 0.31 & 0.37 & & \\
& $f_{\mathrm{x}}^{\prime}$ & 0.27 & 0.28 & & \\
& $X_{\mathrm{t}}$ & 25.3 & 25 & - & - \\
& $X_{\mathrm{v}}$ & 17 & 14.8 & & \\
& $R_{\mathrm{s}}$ & 16 & 13 & & \\
\hline
\end{tabular}

TABLE 1

\begin{tabular}{|c|c|c|c|}
\hline Data at HRT $=6 \mathrm{~h}$ & Influent COD (mg/L) & Raw effluent (mg/L) & Settled effluent $(\mathrm{mg} / \mathrm{L})$ \\
\hline $\begin{array}{l}\text { Average }(\mathrm{mg} / \mathrm{L}) \\
\text { Standard deviation }(\mathrm{mg} / \mathrm{L}) \\
\text { Number of determinations } \\
\text { Operational period }(\mathrm{d})\end{array}$ & $\begin{array}{r}698 \\
124 \\
15 \\
64 \\
\end{array}$ & $\begin{array}{r}198 \\
54 \\
15 \\
64 \\
\end{array}$ & $\begin{array}{r}150 \\
39 \\
15 \\
64 \\
\end{array}$ \\
\hline Data at $\mathrm{HRT}=4 \mathrm{~h}$ & Influent & Raw effluent & Settled effluent \\
\hline $\begin{array}{l}\text { Average }(\mathrm{mg} / \mathrm{L}) \\
\text { Standard deviation }(\mathrm{mg} / \mathrm{L}) \\
\text { Number of determinations } \\
\text { Operational period }(\mathrm{d})\end{array}$ & $\begin{array}{r}672 \\
108 \\
16 \\
60 \\
\end{array}$ & $\begin{array}{r}238 \\
96 \\
16 \\
60 \\
\end{array}$ & $\begin{array}{r}148 \\
53 \\
16 \\
60 \\
\end{array}$ \\
\hline Data at $\mathrm{HRT}=3 \mathrm{~h}$ & Influent & Raw effluent & Settled effluent \\
\hline $\begin{array}{l}\text { Average }(\mathrm{mg} / \mathrm{L}) \\
\text { Standard deviation }(\mathrm{mg} / \mathrm{L}) \\
\text { Number of determinations } \\
\text { Operational period }(\mathrm{d})\end{array}$ & $\begin{array}{r}750 \\
117 \\
15 \\
30 \\
\end{array}$ & $\begin{array}{r}432 \\
132 \\
15 \\
30 \\
\end{array}$ & $\begin{array}{r}232 \\
59 \\
15 \\
30 \\
\end{array}$ \\
\hline Data at $\mathrm{HRT}=2.4 \mathrm{~h}$ & Influent & Raw effluent & Settled effluent \\
\hline $\begin{array}{l}\text { Average }(\mathrm{mg} / \mathrm{L}) \\
\text { Standard deviation }(\mathrm{mg} / \mathrm{L}) \\
\text { Number of determinations } \\
\text { Operational period }(\mathrm{d})\end{array}$ & $\begin{array}{r}776 \\
120 \\
10 \\
30\end{array}$ & $\begin{array}{r}398 \\
70 \\
10 \\
30\end{array}$ & $\begin{array}{r}217 \\
32 \\
10 \\
30\end{array}$ \\
\hline
\end{tabular}

COD concentrations in the influent and the raw and settled affluent for different retention times and a temperature of $25^{\circ} \mathrm{C}$ 
was calculated from the COD data for each retention time by the following procedure:

- Step 1: The settleable effluent COD was converted into an equivalent volatile solids concentration by the constant introduced by Marais and Ekama (1976):

$$
X_{\mathrm{ve}}=\left(S_{\mathrm{ex}}-S_{\mathrm{es}}\right) / f_{\mathrm{cv}}
$$

where:

$X_{\mathrm{ve}}=$ volatile solids concentration in the raw effluent $f_{\mathrm{cv}}^{\mathrm{ve}}=\mathrm{COD} / \mathrm{VSS}$ ratio of volatile sludge $=1.5 \mathrm{mgCOD} / \mathrm{mgVSS}$ Then the volatile sludge mass in the effluent was calculated as the product of the volatile sludge concentration of the effluent and the effluent flow rate:

$$
M X_{\mathrm{ve}}=Q_{i} X_{\mathrm{ve}}
$$

where:

$M X_{\mathrm{ve}}=$ daily expelled volatile sludge mass

$Q_{\mathrm{i}}=$ influent flow rate

- Step 2: The sludge age was calculated as the ratio between the volatile sludge mass in the reactor and the daily sludge mass in the effluent (both determined experimentally).

$$
R_{\mathrm{s}}=M X_{\mathrm{v}} / M X_{\mathrm{ve}}=X_{\mathrm{v}} V_{\mathrm{r}} / Q_{\mathrm{i}} X_{\mathrm{ve}}
$$

where:

$R_{\mathrm{s}}=$ sludge age $=$ mean solids retention time

$M X_{\mathrm{v}}=$ mass of volatile sludge in the reactor

$X_{v}=$ average volatile solids concentration in the reactor

$V_{\mathrm{r}}=$ reactor volume

In order to calculate the sludge age it is necessary to know both the daily discharged sludge mass and the sludge mass in the reactors, $M X_{v}$. The total and volatile sludge mass, calculated from samples of the mixed reactor contents, are also presented in Table 2.

The calculated values of the sludge age at $25^{\circ} \mathrm{C}$ for the different liquid retention times are shown in Table 2 (Column 3). The same operational and calculation procedures shown above for $25^{\circ} \mathrm{C}$ were also applied for the reactors operated at temperatures of 20,15 and $12^{\circ} \mathrm{C}$, and are shown in Table 2 (Columns 4 to 6) as functions of the temperature and the retention time.

Figures $3 \mathrm{a}$ to $3 \mathrm{~d}$ are graphical representations of the experimental data in Table 2 for the different investigated temperatures $\left(12,15,20\right.$ and $\left.25^{\circ} \mathrm{C}\right)$ : the COD fractions in the settled effluent $\left(f_{\mathrm{s}}^{\prime}\right)$ as well as the COD fractions converted into sludge $\left(f_{\mathrm{x}}\right)$ have been marked as functions of the sludge age $\left(R_{\mathrm{s}}\right)$. The experimental data clearly indicate that both temperature and sludge age have an effect on the values of the COD fractions.

Therefore it was attempted to use the experimental data to develop empirical expressions for soluble and settleable fractions of the COD in the effluent as functions of the sludge age and the temperature. In a previous paper (Santos et al., 2016), the relationship between these fractions and the sludge age was evaluated for a single temperature $\left(25^{\circ} \mathrm{C}\right)$ and an empirical expression was derived:

$$
\begin{aligned}
& f_{\mathrm{s}}=0.14+0.25 \cdot \mathrm{e}^{[-0.04(R s-6)]} \\
& f_{x}=0.12+0.20 \cdot \mathrm{e}^{[-0.04(R s-6)]}
\end{aligned}
$$

where:

$f_{\mathrm{s}}, f_{\mathrm{x}}=$ simulated values of COD fractions in the settled effluent and converted into sludge as functions of the sludge age.
In this paper the data in Table 2 were used to extend this empirical relationship to also include temperature. To achieve this objective the following procedure was adopted for the analysis of the experimental data:

\section{Step 1: Non-biodegradable fractions}

The experimental results very clearly indicate that the soluble and the settleable COD fractions in the raw effluent tend towards a constant value for long sludge ages, but these fractions increase with decreasing temperature. It is assumed that the COD fractions at long sludge age are composed of non-biodegradable material: the soluble inert influent material in the case of the soluble fraction and particulate inert influent material plus bacterial sludge in the case of the settleable COD fraction. Considering first the soluble fraction and assuming (i) that an Arrhenius-type expression can be used to account for the increase of inert soluble COD in the influent, and (ii) that the non-biodegradable fraction is minimal at the optimal mesophilic temperature of $35^{\circ} \mathrm{C}$, the data in Figs $3 \mathrm{a}$ to $3 \mathrm{~d}$ indicate that the non-biodegradable soluble fractions as found at long sludge ages $(200 \mathrm{~d})$ can be expressed as:

$$
f_{\text {ust }}=f_{u s 35} 1.037^{(35-\mathrm{t})}=0.15 \times 1.037^{(35-t)}
$$

It must be emphasised that the values of the nonbiodegradable fraction in the anaerobic environment are much bigger than those in aerobic systems, where fractions of the order of $f_{u s t}=0.10$ have been reported, independent of the temperature. Possibly this can be attributed to the fact that at the time the sewerage network was partially blocked, so that the network itself could start to function as an anaerobic reactor digesting some of the biodegradable material and thus increasing the non-biodegradable soluble fraction. At the same time the non-biodegradable particulate fraction could increase through setting in the network.

The experimental data in Figs 3a to 3d can be used to derive an expression for the non-biodegradable particulate fraction:

$$
f_{\text {upt }}=f_{\text {up } 35^{3}} 1.015^{(35-t)}=0.07^{\star} 1.015^{(35-t)}
$$

However, it must be noted that this fraction covers not only the inert particulate material in the influent, but also the fraction that is transformed into biological sludge, i.e., the masses of the bacterial and archea populations.

\section{Step 2: Biodegradable and total soluble fraction in the settled effluent}

The biodegradable soluble effluent fraction is the difference between the soluble effluent fraction $f_{s}$ (Eq. 2) and the nonbiodegradable soluble fraction $f_{\text {ust }}$ (Eq. 7). Hence:

$$
f_{\mathrm{bst}}=f_{\mathrm{s}}-f_{\mathrm{ust}}
$$

Now, taking into account earlier work that led to Eq. 7, an empirical expression was found by trial and error, giving good correlation between the experimental and simulated values of the soluble COD fraction:

$$
f_{\text {bst }}=0.20(1.011)^{(t-35)} \mathrm{e}^{(-0.04(R s-3.8 \times 1.06(35-t)))}
$$

and

$$
f_{\mathrm{s}}=f_{\text {ust }}+f_{\text {bst }}=f_{\text {us } 35} 1.037^{(35-t)}+0.20(1.011)^{(t-35)} \mathrm{e}^{(-0.04(R s-3.8 \times 1.06(35-t)))}
$$


R12

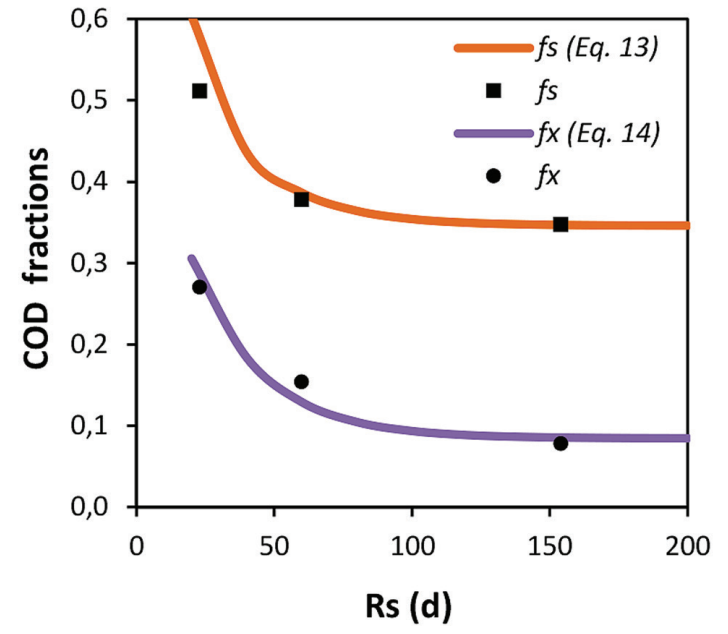

Figure $3 a$

Experimental and simulated $\left(f_{s}^{\prime}\right.$ and $f_{x}^{\prime}$ ) values of $C O D$ fractions as functions of $R_{s}$ at $12^{\circ} \mathrm{C}$

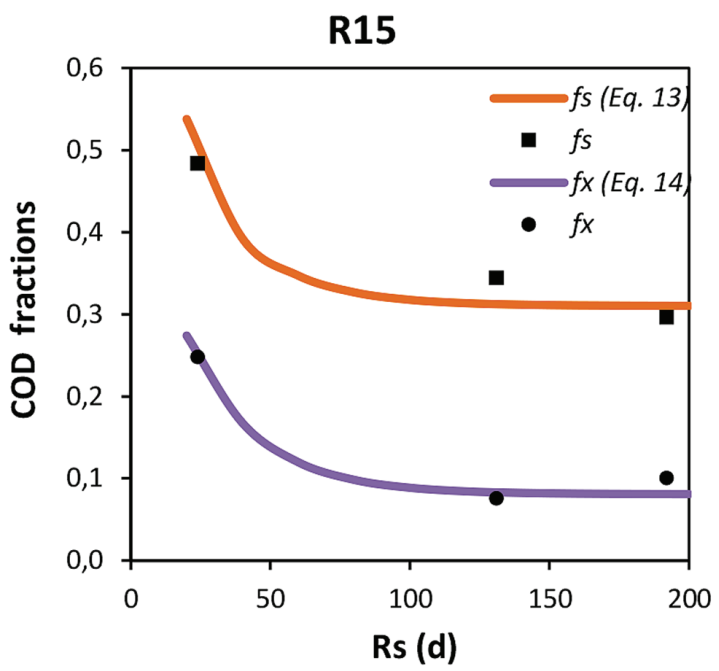

Figure $3 \boldsymbol{b}$

Experimental and simulated ( $f_{s}^{\prime}$ and $f_{x}^{\prime}$ ) values of $C O D$ fractions as functions of $R_{s}$ at $15^{\circ} \mathrm{C}$

In Eq. 12 the term $3.8 \times 1.06^{(35-t)}$ represents the minimum sludge age for anaerobic digestion to be feasible at different temperatures. For sludge ages larger than the minimum Eq. 12 shows the fraction of the influent COD that is in the effluent as biodegradable COD. The increasing fraction with decreasing sludge age indicates that the biological processes become progressively incapable of transforming soluble biodegradable substrates into methane. However, measurements of the volatile fatty acids (VFA) in the effluent showed that this substrate for methanogens did not increase considerably or consistently at short sludge ages. Therefore, it was concluded that the observed inefficiency was due to incomplete acidogenisis and acetogenisis rather than to incomplete methanogenisis.

Using the empirical equation of Eq. 13 in Figs 3a to 3d, curves are drawn to show the simulated value of $f_{\mathrm{s}}$ as a function
R20

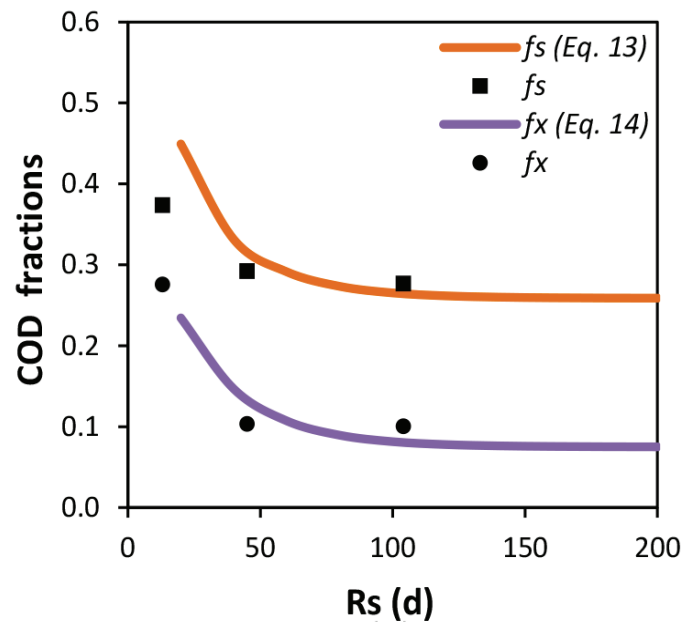

Figure 3c

Experimental and simulated $\left(f_{s}^{\prime}\right.$ and $\left.f_{x}^{\prime}\right)$ values of COD fractions as functions of $R_{s}$ at $25^{\circ} \mathrm{C}$

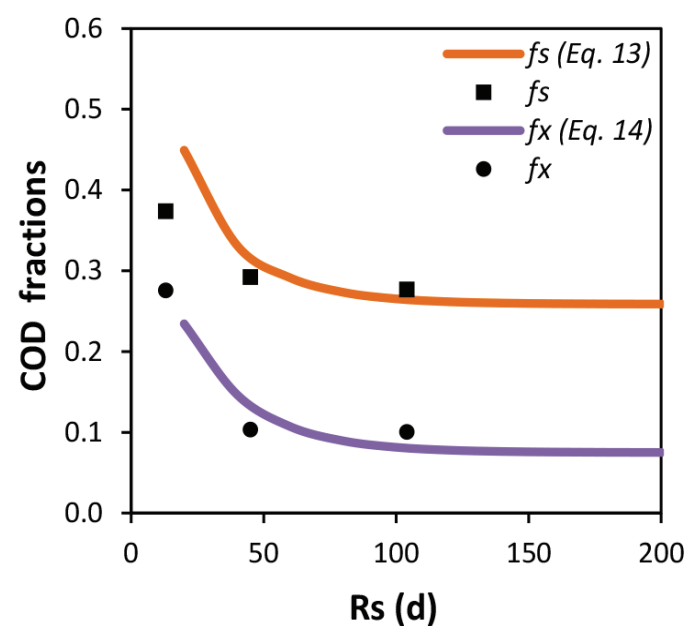

Figure $3 d$

Experimental and simulated ( $f_{s}^{\prime}$ and $\left.f_{x}^{\prime}\right)$ values of COD fractions as functions of $R_{s}$ at $25^{\circ} \mathrm{C}$

of the sludge age for the different temperatures in the reactors. It can be seen that a close correlation was obtained between the experimental (also indicated in the figures) and simulated values of the COD fraction in the settled effluent for all sludge ages and all temperatures, whence it is concluded that Eq. 13 is an adequate expression for this fraction.

\section{Step 3: Particulate fraction}

Figure $3 \mathrm{a}$ to $3 \mathrm{~d}$ also shows the experimental settleable COD fraction discharged from the UASB reactor, $f_{\mathrm{x}}$. The experimental fraction $f_{\mathrm{x}}$ as calculated from Eq. 3 , tends to decrease with increasing temperature and increasing sludge age, but the decrease is less pronounced than in the case of the experimental fraction $f_{\mathrm{s}}$ in Eq. 2 . It is considered that the fraction $f_{\mathrm{x}}$ is composed of three components: (i) an inert 
fraction generated from flocculation of non-biodegradable influent organic material (ii) biological sludge, the bacterial and archea mass and (iii) biodegradable and particulate influent organic material that is not hydrolysed in the reactor, but discharged as excess sludge.

At long sludge ages $(>100 \mathrm{~d})$ the fraction $f_{\mathrm{x}}$ is essentially constant, indicating that the metabolism of the particulate material is largely complete. In that case the sludge is composed only of inert material and biological sludge, but it is not known what the proportion of each is. At any rate this fraction is small $\left(f_{\mathrm{x}} \approx 0.08\right.$ at $25^{\circ} \mathrm{C}$ and $\left.>100 \mathrm{~d}\right)$ and it decreases with increasing temperature. Thus, it is concluded that under real operational conditions, where the sludge typically is much smaller than $100 \mathrm{~d}$, part of the solids being discharged from UASB reactors is actually non-hydrolysed particulate influent organic material.

An estimate of the inert and biological fraction at long sludge ages can be can be made as follows: at $25^{\circ} \mathrm{C}$ and $200 \mathrm{~d}$ sludge age the fraction $f_{\mathrm{x}}=0.08$ was found. If it is assumed that the non-biodegradable particulate COD fraction is not less than $3 \%$ of the total COD (indeed generally higher values have been reported), the COD fraction that is converted into biological sludge is $0.08-0.03=0.05$. On the other hand, for $\mathrm{T}=25^{\circ} \mathrm{C}$ and $R_{\mathrm{s}}=200 \mathrm{~d}$, the soluble fraction in the effluent is 0.22 (Fig. 3d). Together with the inert fraction this means that $25 \%$ of the influent COD is not digested, and hence $75 \%$ is. Thus a COD fraction of $0.75 \times 1.5 \times Y$ is converted into sludge representing a fraction of 0.05 . Thus it is calculated that the yield factor is $Y=0.05,(0.75 \times 1.5)=0.044 \mathrm{~g} \mathrm{X} / \mathrm{gCOD}$. This is a feasible value since the minimum value is $0.02 \mathrm{gX}_{\mathrm{v}} / \mathrm{gCOD}$ for methanogens (Henze and Harremoes, 1983), but a larger sludge production would be expected since there are also bacterial populations. A value of $Y \approx 0.05 \mathrm{mgVSS} / \mathrm{mgCOD}$ has been reported (Santos et al., 2016; Wentzel et al., 2006; Ikumi et al., 2014). It is important to stress that for the experimental data it was necessary to assume a low value of the non-biodegradable particulate COD fraction. Indirectly this low fraction favours anaerobic digestion since it leads to low accumulation of inert material in the reactor and hence a long sludge age. A larger inert fraction would have led to a shorter sludge age and hence a lower digestion efficiency.

Taking into account the available experimental data, an empirical expression for the COD fraction that is converted into sludge in a UASB reactor can be derived, assuming that this fraction is influenced by two operational parameters: temperature and sludge age. If again it is considered that the minimum non-biodegradable particulate influent COD fraction is found at $35^{\circ} \mathrm{C}$ the expression is:

$$
f_{\mathrm{x}}=f_{\text {up } 35} 1.015^{(35-t)}+0.16 \times 1.014^{(35-t)} \mathrm{e}^{(-0.04(R s-3.8 \times 1.06(35-t)))}
$$

As Figure $3 \mathrm{a}$ to $3 \mathrm{~d}$ shows, there is a good correlation between experimental and simulated values for the influent COD fraction that is converted into sludge for all sludge ages and temperatures.

\section{Step 4: Digested fraction}

Having established the fractions of the influent COD that end up in the effluent and in the sludge, the fraction that is actually digested is now expressed as:

$$
f_{\mathrm{d}}=1-f_{\mathrm{s}}-f_{\mathrm{x}}
$$

Ideally the measured $\mathrm{CH}_{4}$ production should be equal to the calculated production from Eq. 15. The calculated methane production $\left(\mathrm{gCH}_{4} / \mathrm{d}\right)$ is readily determined knowing that the mass of produced methane is one quarter of the mass of digested COD (Van Haandel and Lettinga, 1994).

$$
M_{\mathrm{CH} 4}=f_{\mathrm{d}} M S_{\mathrm{ti}} / 4=f_{\mathrm{d}} Q_{\mathrm{i}} S_{\mathrm{ti}} / 4
$$

where:

$M_{C H 4}=$ daily mass of produced methane

$M S_{\mathrm{ti}}=$ daily mass of applied COD

$Q_{\mathrm{i}}=$ influent flow rate

$S_{\mathrm{ti}}=$ influent COD

In actual fact the obtained methane in the biogas will not be equal to the theoretical mass of Eq. 16 for two reasons: (i) a small fraction of the organic material many be oxidised by sulphate, a process that develops parallel to anaerobic digestion, and (ii) a fraction of the produced methane will remain dissolved in the liquid phase and be discharged together with the effluent. Since the wastewater that was used had a very low sulphate concentration $\left(2-4 \mathrm{mg} / \mathrm{L} \mathrm{SO}_{4}\right)$, the oxidised fraction could be neglected. The part of dissolved methane can be calculated on the basis of Henry's law on solubility of gases: when a liquid and a gas phase are in equilibrium the gas solubility (saturation concentration) in the liquid is proportional to the pressure in the gas phase. The fraction of methane that remains dissolved can be calculated and increases with decreasing temperature: the methane production tends to decrease and the solubility tends to increase. For a combination of low temperature and short sludge age, more than $50 \%$ of the methane can remain dissolved.

Figure 4 shows the calculated values of the total methane production, calculated from Eq. 16. From Fig. 4 the following points become apparent:

- There is no point in increasing the sludge age above about $100 \mathrm{~d}$ since the digestion efficiency is at or near its maximum for this value for all investigated temperatures

- Even under favourable conditions, i.e., at high sludge ages and high temperatures, the methane production from sewage is small and productive use is only economical for big systems, such as for $>500000$ (inhabitant equivalent)

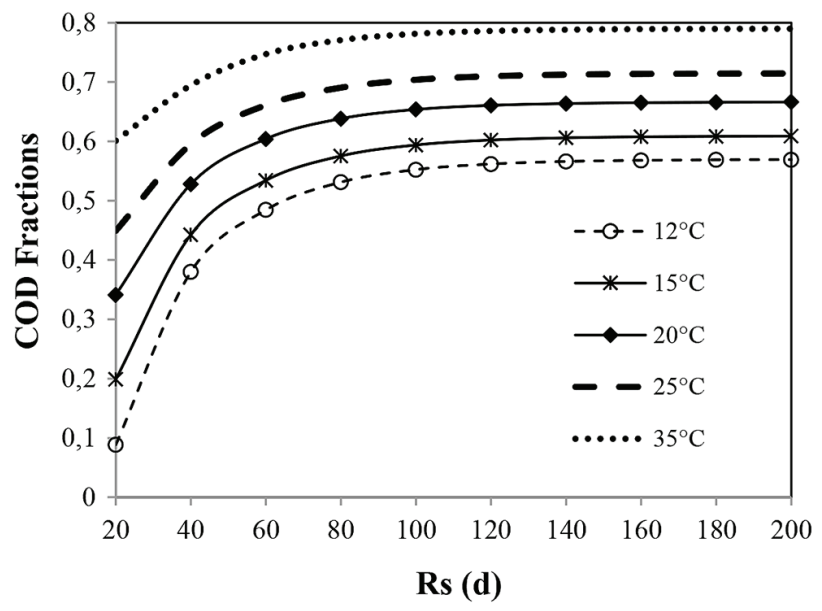

Figure 4

Total COD fraction that is converted into methane and fraction that remains dissolved in the liquid phase a function of the sludge age for different temperatures: $35,25,20,15$ and $12^{\circ} \mathrm{C}$ 
- The maximum digestion efficiency strongly depends on temperature: at $25^{\circ} \mathrm{C}$ the maximum digestion efficiency was about $70 \%$, whereas at $12^{\circ} \mathrm{C}$ it was only slightly more than $50 \%$

- The dissolved methane is a considerable fraction of the total production, especially at low temperatures and short sludge ages

In addition to the investigation to determine the effect of temperature and sludge age on the efficiency of digestion, the influence of these operational parameters on the sludge characteristics, as expressed by its settleability and activity, was investigated. Table 3 a shows the values of the settleability constants for the sludges in the four reactors for the different temperatures and retention times. Table $3 \mathrm{~b}$ shows the values for the sludges expelled from the reactors. The data presented in Tables $3 \mathrm{a}$ and $3 \mathrm{~b}$ show that the sludge settleability was only marginally influenced by the retention time (or sludge age) and the temperature. By contrast the values of the constants of the sludges in the reactor were very different from those of the sludges expelled from the reactors. The settleability of the expelled sludges was greatly inferior to that of the sludges in the reactors.

It is interesting to compare the sludge mass that was retained in the reactors with the theoretical mass that could be retained in accordance with the actual mass that was measured. For example, for $H R T=6 \mathrm{~h}$ and $T=25^{\circ} \mathrm{C}$, the values of the constants are $k=0.06 \mathrm{~L} / \mathrm{g}$ and $v_{\mathrm{o}}=9 \mathrm{~m} / \mathrm{h}$. For $H R T=6 \mathrm{~h}$ and a reactor height of $1.35 \mathrm{~m}$ (Fig. 2) the liquid velocity is $1.35 / 6=0.22 \mathrm{~m} / \mathrm{h}$. Thus with Vesilind's Equation $0.22=9^{*} \mathrm{e}^{(0.06 \mathrm{Xt})}$ and $X_{t}=61 \mathrm{~g} / \mathrm{L}$.

It is concluded that the actual sludge concentration of about $27 \mathrm{~g} / \mathrm{L}$ was very much smaller than the theoretical maximum. The settling characteristics of the sludge that was expelled from the reactor $\left(k=0.21 \mathrm{~L} / \mathrm{g}\right.$ and $\left.v_{\mathrm{o}}=27 \mathrm{~m} / \mathrm{h}\right)$ would allow a sludge concentration $X_{t}=23 \mathrm{~g} / \mathrm{L}$, which is of the same order of magnitude as the actually measured sludge concentration in the reactor. This clearly indicates that the sludge in the effluent was the result of floc erosion in the reactors, producing small flocs with poor settleability that could not be held in the reactor. Subsequently, in the reservoir holding the effluent, the small particles form larger flocs with better settleability through flocculation. It is concluded that the sludge hold-up in UASB reactors is not only determined primarily by sludge settleability: particle break-up is an important factor in the capacity of sludge retention (and hence treatment capacity) of UASB reactors.

Table 4 shows the values of the SMA of the sludges in the reactors and expelled from them for the different temperatures and retention times that were applied.

The SMA values of sludges in the reactors were approximately the same as the values for sludges expelled from the reactors when operational conditions were comparable. The SMA data can be used to calculate the methanogenic treatment capacity of the reactors and compare these values with the

\begin{tabular}{|c|c|c|c|c|c|}
\hline \multicolumn{6}{|c|}{$\begin{array}{l}\text { TABLE } 3 \mathrm{~A} \\
\begin{array}{c}\text { Values of the settleability constants } k \text { and } v_{\mathrm{o}} \text { of sludge in the reactors as functions } \\
\text { of temperature and retention time }\end{array}\end{array}$} \\
\hline HRT & Parameter & $T=25^{\circ} \mathrm{C}$ & $T=20^{\circ} \mathrm{C}$ & $T=15^{\circ} \mathrm{C}$ & $T=12^{\circ} \mathrm{C}$ \\
\hline $8 \mathrm{~h}$ & $\begin{array}{l}k(\mathrm{~L} / \mathrm{g}) \\
v_{\mathrm{o}}(\mathrm{m} / \mathrm{h})\end{array}$ & - & - & $\begin{array}{c}0.12 \\
13\end{array}$ & $\begin{array}{c}0.13 \\
16\end{array}$ \\
\hline $6 \mathrm{~h}$ & $\begin{array}{c}k(\mathrm{~L} / \mathrm{g}) \\
v_{\mathrm{o}}(\mathrm{m} / \mathrm{h})\end{array}$ & $\begin{array}{c}0.06 \\
9\end{array}$ & $\begin{array}{c}0.08 \\
10\end{array}$ & $\begin{array}{c}0.14 \\
14\end{array}$ & $\begin{array}{c}0.16 \\
19\end{array}$ \\
\hline $4 \mathrm{~h}$ & $\begin{array}{l}k(\mathrm{~L} / \mathrm{g}) \\
v_{\mathrm{o}}(\mathrm{m} / \mathrm{h})\end{array}$ & $\begin{array}{c}0.11 \\
16\end{array}$ & $\begin{array}{c}0.11 \\
22\end{array}$ & $\begin{array}{c}0.13 \\
13\end{array}$ & $\begin{array}{c}0.14 \\
16\end{array}$ \\
\hline $3 \mathrm{~h}$ & $\begin{array}{c}k(\mathrm{~L} / \mathrm{g}) \\
v_{\mathrm{o}}(\mathrm{m} / \mathrm{h})\end{array}$ & $\begin{array}{c}0.15 \\
24 \\
\end{array}$ & $\begin{array}{c}0.16 \\
16 \\
\end{array}$ & - & - \\
\hline $2.4 \mathrm{~h}$ & $\begin{array}{c}k(\mathrm{~L} / \mathrm{g}) \\
v_{\mathrm{o}}(\mathrm{m} / \mathrm{h})\end{array}$ & $\begin{array}{c}0.11 \\
13\end{array}$ & $\begin{array}{c}0.12 \\
14\end{array}$ & - & - \\
\hline
\end{tabular}

\begin{tabular}{|c|c|c|c|c|c|}
\hline \multicolumn{6}{|c|}{$\begin{array}{l}\text { TABLE 3B } \\
\text { Values of the settleability constants } k \text { and } v_{\circ} \text { of sludge expelled from the reactors as functions of } \\
\text { temperature and retention time }\end{array}$} \\
\hline HRT & Parameter & $T=25^{\circ} \mathrm{C}$ & $T=20^{\circ} \mathrm{C}$ & $T=15^{\circ} \mathrm{C}$ & $T=12^{\circ} \mathrm{C}$ \\
\hline $8 \mathrm{~h}$ & $\begin{array}{c}k(\mathrm{~L} / \mathrm{g}) \\
v_{\mathrm{o}}(\mathrm{m} / \mathrm{h})\end{array}$ & - & - & $\begin{array}{c}0.28 \\
18 \\
\end{array}$ & $\begin{array}{c}0.22 \\
13\end{array}$ \\
\hline $6 \mathrm{~h}$ & $\begin{array}{l}K(\mathrm{~L} / \mathrm{g}) \\
v_{\mathrm{o}}(\mathrm{m} / \mathrm{h})\end{array}$ & $\begin{array}{c}0.21 \\
27 \\
\end{array}$ & $\begin{array}{c}0.28 \\
18 \\
\end{array}$ & $\begin{array}{c}0.19 \\
20 \\
\end{array}$ & $\begin{array}{c}0.19 \\
23 \\
\end{array}$ \\
\hline $4 \mathrm{~h}$ & $\begin{array}{l}K(\mathrm{~L} / \mathrm{g}) \\
v_{\mathrm{o}}(\mathrm{m} / \mathrm{h})\end{array}$ & $\begin{array}{c}0.20 \\
14 \\
\end{array}$ & $\begin{array}{c}0.19 \\
20 \\
\end{array}$ & $\begin{array}{c}0.21 \\
15\end{array}$ & $\begin{array}{c}0.18 \\
20 \\
\end{array}$ \\
\hline $3 \mathrm{~h}$ & $\begin{array}{c}K(\mathrm{~L} / \mathrm{g}) \\
v_{\mathrm{o}}(\mathrm{m} / \mathrm{h})\end{array}$ & $\begin{array}{c}0.18 \\
13\end{array}$ & $\begin{array}{c}0.14 \\
8\end{array}$ & - & - \\
\hline $2.4 \mathrm{~h}$ & $\begin{array}{l}K(\mathrm{~L} / \mathrm{g}) \\
v_{\mathrm{o}}(\mathrm{m} / \mathrm{h})\end{array}$ & $\begin{array}{c}0.13 \\
10\end{array}$ & $\begin{array}{c}0.12 \\
13\end{array}$ & - & - \\
\hline
\end{tabular}


biodegradable organic load. The methanogenic treatment capacity can be expressed as:

$$
P_{\mathrm{CH} 4}=S M A \times M X_{\mathrm{t}}
$$

The biodegradable organic load is calculated as:

$$
M S_{\mathrm{bi}}=M S_{\mathrm{ti}}\left(1-f_{\mathrm{ust}}-f_{\mathrm{upt}}\right)
$$

In Table 5 the methanogenic treatment capacity is compared to the biodegradable organic load for the different temperatures and liquid retention times. It can be seen in most cases that the biodegradable load is much bigger than the methanogenic potential of the sludge mass. However, even at low temperatures and short retention times (high loads) the methanogenic treatment capacity was sufficient for efficient removal of the methanogenic substrate: the volatile fatty acid concentration (VFA) was never high $(<2$ $\mathrm{meq} / \mathrm{L})$ for all investigated temperatures and organic loading rates. It was concluded that in the case of sewage treatment a reduction of the digestion efficiency at low temperatures and high loading rates is not due only to a reduction of the methanogenisis efficiency: the reduction of the rate of preparatory processes (hydrolysis, acidogenisis and acetogenisis) is much more important.

The experimental data clearly show that the efficiency of COD removal by anaerobic digestion of raw sewage decreases as the sewage temperature decreases from its optimal mesophilic value at $35-37^{\circ} \mathrm{C}$. On the one hand this is due to the decreased rates of the preparatory processes of acidogenisis and acetogenisis and also to the lower rate of methanogenisis itself, that leads to a larger concentration of soluble biodegradable organic material in the settled effluent. On the other hand, there is the decreased hydrolysis rate of particulate biodegradable organic material in the influent. The material that is not hydrolysed tends to flocculate and accumulate in the reactor as a fraction of the sludge. Hence when hydrolysis is slow the sludge production rate is high and since the sludge mass than can be held in the reactor is substantially constant, the sludge age decreases, which in itself is a reason for a worse performance of the anaerobic digestion process.

The applicability of anaerobic digestion at lower

\begin{tabular}{|c|c|c|c|c|c|}
\hline \multicolumn{6}{|c|}{$\begin{array}{l}\text { TABLE } 4 \\
\begin{array}{c}\text { Values of specific methanogenic activity of sludges in the reactors and expelled from these as functions of } \\
\text { temperature and retention time }\end{array}\end{array}$} \\
\hline Retention time & Parameter & $T=25^{\circ} \mathrm{C}$ & $T=20^{\circ} \mathrm{C}$ & $T=15^{\circ} \mathrm{C}$ & $T=12^{\circ} \mathrm{C}$ \\
\hline \multirow{2}{*}{$12 \mathrm{~h}$} & $S M A_{\text {reactor }}$ & - & - & 0.034 & 0.022 \\
\hline & $S M A_{\text {expelled }}$ & - & - & $\mathrm{ND}^{*}$ & $\mathrm{ND}^{*}$ \\
\hline $8 \mathrm{~h}$ & $\begin{array}{l}S M A_{\text {reactor }} \\
S M A_{\text {expelled }}\end{array}$ & $\begin{array}{l}- \\
- \\
\end{array}$ & $\begin{array}{l}- \\
- \\
\end{array}$ & $\begin{array}{l}0.048 \\
0.045 \\
\end{array}$ & $\begin{array}{l}0.024 \\
0.020 \\
\end{array}$ \\
\hline $6 \mathrm{~h}$ & $\begin{array}{l}S M A_{\text {reactor }} \\
S M A_{\text {expelled }}\end{array}$ & $\begin{array}{l}0.124 \\
0.110 \\
\end{array}$ & $\begin{array}{l}0.073 \\
0.069 \\
\end{array}$ & $\begin{array}{l}0.061 \\
0.058 \\
\end{array}$ & $\begin{array}{l}0.058 \\
0.060 \\
\end{array}$ \\
\hline $4 \mathrm{~h}$ & $\begin{array}{l}S M A_{\text {reactor }} \\
S M A_{\text {expelled }}\end{array}$ & $\begin{array}{l}0.149 \\
0.136 \\
\end{array}$ & $\begin{array}{l}0.122 \\
0.114\end{array}$ & $\begin{array}{l}0.012 \\
0.010 \\
\end{array}$ & $\begin{array}{l}0.018 \\
0.020 \\
\end{array}$ \\
\hline $3 \mathrm{~h}$ & $\begin{array}{l}S M A_{\text {reactor }} \\
S M A_{\text {expelled }}\end{array}$ & $\begin{array}{l}0.125 \\
0.118 \\
\end{array}$ & $\begin{array}{l}0.062 \\
0.072 \\
\end{array}$ & - & - \\
\hline $2,4 \mathrm{~h}$ & $\begin{array}{l}S M A_{\text {reactor }} \\
S M A_{\text {expelled }}\end{array}$ & $\begin{array}{l}0.126 \\
0.122\end{array}$ & $\begin{array}{l}0.061 \\
0.064\end{array}$ & - & $\begin{array}{l}- \\
-\end{array}$ \\
\hline
\end{tabular}
temperatures could be extended somewhat by increasing the

${ }^{*}$ ND: not determined value

TABLE 5

Comparison of the methanogenic treatment capacity and the applied biodegradable organic load as functions

\begin{tabular}{|c|c|c|c|c|c|}
\hline HRT & Parameter & $T=25^{\circ} \mathrm{C}$ & $T=20^{\circ} \mathrm{C}$ & $T=15^{\circ} \mathrm{C}$ & $T=12^{\circ} \mathrm{C}$ \\
\hline $12 \mathrm{~h}$ & $\begin{array}{l}P_{\mathrm{CH} 4} \\
M S_{b \mathrm{bi}}\end{array}$ & - & - & $\begin{array}{l}17.8 \\
17.05\end{array}$ & $\begin{array}{l}11.4 \\
15.9\end{array}$ \\
\hline $8 \mathrm{~h}$ & $\begin{array}{l}P_{\mathrm{CH} 4} \\
M S_{\mathrm{bi}}\end{array}$ & - & - & $\begin{array}{l}18.9 \\
31.67\end{array}$ & $\begin{array}{l}10.1 \\
29.62\end{array}$ \\
\hline $6 \mathrm{~h}$ & $\begin{array}{l}P_{\mathrm{CH} 4} \\
M S_{b \mathrm{bi}}\end{array}$ & $\begin{array}{l}70.8 \\
50.03\end{array}$ & $\begin{array}{l}42.4 \\
46.64\end{array}$ & $\begin{array}{l}26.7 \\
40.80\end{array}$ & $\begin{array}{l}23.8 \\
38.16\end{array}$ \\
\hline $4 \mathrm{~h}$ & $\begin{array}{l}P_{\mathrm{CH} 4} \\
M S_{\mathrm{bi}}\end{array}$ & $\begin{array}{l}69.6 \\
72.18\end{array}$ & $\begin{array}{l}59.4 \\
67.30\end{array}$ & $\begin{array}{c}5.6 \\
68.20\end{array}$ & $\begin{array}{c}6.6 \\
63.79\end{array}$ \\
\hline $3 \mathrm{~h}$ & $\begin{array}{l}P_{\mathrm{CH} 4} \\
M S_{b i}\end{array}$ & $\begin{array}{c}58.1 \\
107.20\end{array}$ & $\begin{array}{l}19.1 \\
99.95\end{array}$ & - & - \\
\hline $2.4 \mathrm{~h}$ & $\begin{array}{l}P_{\mathrm{CH} 4} \\
M S_{\mathrm{bi}}\end{array}$ & $\begin{array}{c}49.3 \\
138.64\end{array}$ & $\begin{array}{l}20.8 \\
29.26\end{array}$ & - & - \\
\hline
\end{tabular}
of temperature and retention time 
sludge age or by using the combustion heat of the produced methane to increase part of the sewage to be treated. In this context three measures look particularly promising: (i) increasing the sludge mass in the reactor by increasing the reactor volume or applying a more efficient phase separator, (ii) separation of settleable solids from the influent before anaerobic digestion and heating the primary sludge in a separate reactor to increase the hydrolysis rate, and (iii) recycling discharged sludge in the effluent after separation by settling, thus increasing the sludge mass in the reactor.

\section{Increase of the sludge mass}

The influence of the phase separator on the performance of the UASB reactor has been discussed in a previous paper (Santos et al., 2016). It was concluded that more efficient sludge retention by the phase separator led to an increase in the sludge mass and hence to an increase of the sludge age. With respect to increasing the reactor volume and retention time the following may be observed: The experimental data in Table 2 indicate that the average sludge concentration during the experimental investigation was about $X_{\mathrm{v}}=17 \mathrm{gVSS} / \mathrm{L}$ or $M X_{\mathrm{v}}=423 \mathrm{~g}$ VSS and that these values were only marginally influenced by temperature and sludge age. However, the volatile solids production rate can be expressed as:

$$
R_{\mathrm{x}}=f_{\mathrm{x}} M S_{\mathrm{ti}} / f_{\mathrm{cv}}=f_{\mathrm{x}} Q_{\mathrm{i}} S_{\mathrm{ti}} / f_{\mathrm{cv}}
$$

where:

$R_{\mathrm{x}}=$ volatile sludge production rate $(\mathrm{gVSS} / \mathrm{d})$

$f_{\mathrm{x}}=$ is fraction of the influent COD that is converted into sludge

(Eq. 3 or 14 )

$M S_{\mathrm{ti}}=$ organic influent load $(\mathrm{gCOD} / \mathrm{d})$

$Q_{\mathrm{i}}=$ sewage glow rate $(\mathrm{L} / \mathrm{d})$

$S_{\mathrm{ti}}=$ influent COD concentration $(\mathrm{g} / \mathrm{L})$

$f_{c v}=$ conversion factor $=1.5 \mathrm{VSS} / \mathrm{COD}$

Thus the sludge age can now be expressed as the ratio between the sludge mass and the sludge production rate:

$$
R_{\mathrm{s}}=M X_{\mathrm{v}} / R_{\mathrm{x}}
$$

In Fig. 4 it is clear than there is no need to operate a UASB reactor at a sludge age of more than $100 \mathrm{~d}$, because the digestion efficiency is at near maximum for this sludge age

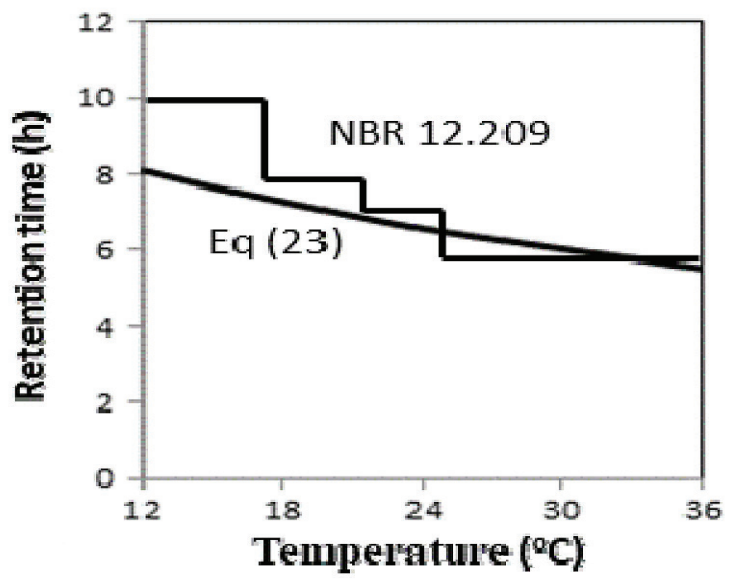

Figure 5

Required HRT for maximum digestion efficiency (sludge age $=100 \mathrm{~d}$ ) as a function of temperature for all temperatures. Thus for maximum performance of the anaerobic digestion process:

$$
M X_{\mathrm{v}}=V_{\mathrm{r}} X_{\mathrm{v}}=100 R_{100 \mathrm{x}}
$$

and

$$
V_{\mathrm{r}}=R_{\mathrm{s}} R_{\mathrm{x}} / X_{\mathrm{v}}=100 R_{100 \mathrm{x}} / 17
$$

So

$$
H R T=V_{\mathrm{r}} / Q_{\mathrm{i}}=R f_{\mathrm{x}} S_{\mathrm{ta}} /\left(f_{\mathrm{cv}} X_{\mathrm{v}}\right)=100 f_{100 x} S_{\mathrm{ta}} /(1.5 \times 17)
$$

where:

$f_{100 \mathrm{x}}=$ COD fraction transformed into sludge when sludge age is $100 \mathrm{~d}$. $R_{100 \mathrm{x}}=$ sludge production rate for a sludge age of $100 \mathrm{~d}$.

\section{$V_{\mathrm{r}}=$ reactor volume}

Figure 5 shows the required hydraulic retention time as a function of the temperature for maximum digestion efficiency, i.e., for $R_{\mathrm{s}}=100 \mathrm{~d}, S_{\mathrm{ti}}=0.8 \mathrm{~g} / \mathrm{L}$ and $X_{\mathrm{v}}=17 \mathrm{~g} / \mathrm{L}$. It is important to stress that the values of the COD concentration and the sludge concentration in the reactors are the average values during the experimental investigation and could be different for other conditions. In particular, the non-biodegradable fractions of the raw sewage would be different if the sewerage system had been working better and this would have had an impact of the performance of the reactors. The calculated value of the retention time for maximum efficiency of the UASB reactor can be compared with the value recommended by the Brazilian Standard, NBR 12.209 (ABNT, 2011). This standard specifies the residence time as a function of the temperature, as also shown in Eq. 23. The retention time of the standard was established by observations of the organic material removal efficiency in real-scale UASB systems operating in Brazil. It can be observed that there is a good correlation between the retention time for maximum efficiency of anaerobic digestion calculated from the data presented in this section and the value recommended by NBR 12.209/2011.

In Fig. 6 the maximum fraction of digested COD, calculated from Eq. 15 is shown plotted as a function of the temperature for a sludge age of $100 \mathrm{~d}$. Now, to assess the feasibility of anaerobic sewage treatment in a particular design situation, it must be evaluated if for the sewage temperature it is worthwhile to

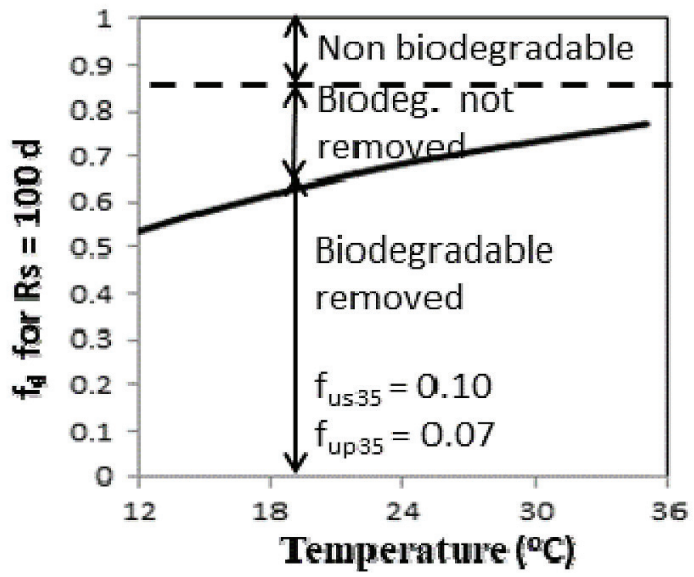

Figure 6

Maximum digestion efficiency as a function of temperature for a sludge age of $100 \mathrm{~d}$ and an assumed volatile sludge concentration of $17 \mathrm{~g} / \mathrm{L}$ 
construct a UASB reactor with the required retention time for near maximum digestion efficiency (Fig. 5), knowing the fraction of the influent COD that is going to be digested (Fig. 6), as well as the fractions, in the effluent and converted into sludge (Eqs 13 and 14), which may require additional (aerobic) treatment, especially if the temperature is low.

\section{Separation of settleable solids}

A large fraction of the organic material in raw sewage (generally more than $50 \%$ ) can be separated by applying gravity settling or more advanced processes (sieving under pressure) prior to anaerobic treatment. The separated settleable solids can be concentrated in a small flow $(<1 \%)$, in the case of settling, or are produced as a cake with an even smaller volume by mechanical processes (Ghasimi et al., 2015). The small flow opens possibilities for using the combustion heat of the methane produced in the UASB reactor to operate a treatment unit for separated solids at a higher temperature, i.e., the optimal mesophilic or thermophilic temperature. Thus hydrolysis and possibly also methanogenisis could be completed at a much higher rate and efficiency than would be possible at the temperature of the sewage.

The solids separation has far-reaching consequences for the anaerobic digestion process: not only can hydrolysis, the rate-limiting process of anaerobic digestion, be accelerated, but also after hydrolysis the material that is not solubilised can be separated and retained while the hydrolysed material is transferred to the UASB reactor. Thus, it is effectively avoided that particulate influent organic material (be it inert or biodegradable) is introduced into the reactor. In that case the sludge would be composed basically of the populations of the anaerobic digestion process and therefore the sludge mass would be a small fraction of the organic load and a long sludge age could be maintained, even if the volume of the reactor was small. It is unclear if such a sludge would have suitable settleability

\section{Sludge recycling}

It was shown that the sludge mass in the UASB reactors was always very much smaller than the mass that could be retained according to its settleability. It was concluded that particle break up and not settleability is the main reason for sludge loss from UASB reactors. However, it was also shown that the solids in the effluent of the reactors tended to flocculate to form well-settling flocs. Therefore it is possible that sludge in the effluent can be separated and eventually returned to the reactor, after a treatment to increase the settleability, for example, with the use of electrolytes. Thus the reactor could then be operated at a larger sludge mass and therefore longer sludge age, and hence have a better performance. Naturally the sludge return cannot be total: there is a maximum to the sludge hold-up in the reactor, limiting the sludge mass. If the maximum is reached any additional sludge will simply lead to a discharge of an equivalent mass with the effluent.

\section{CONCLUSIONS}

- Both temperature and sludge age have a strong impact on the efficiency of anaerobic reactors treating raw sewage.

- In the range of temperature of 12 to $35^{\circ} \mathrm{C}$ there is no point in operating anaerobic systems at a sludge age of more than about $100 \mathrm{~d}$, when the digestion efficiency is maximum.

- A lower temperature leads to a strong increase of both the non-biodegradable and the biodegradable COD fraction in the effluent, although the methanogenisis process remains efficient even at low temperatures

- At low temperatures hydrolysis is inefficient and the main reason for poor performance of anaerobic sewage treatment systems: not only is the particulate biodegradable COD converted into sludge, it then occupies space in the reactor, leading to a reduction of the sludge age.

- There are possibilities to increase the performance of anaerobic treatment systems at low temperature: (i) increase the sludge mass by increasing the reactor volume and/or the efficiency of sludge retention, (ii) application of (settleable) solids separation of the sewage prior to anaerobic treatment, and (iii) recycle sludge, so that the sludge mass in the reactor is always kept at its maximum value.

- Although UASB sludge treating sewage is flocculent and not granular, its settleability is very good and would allow a much higher mass in the reactor; particle break-up rather than settleability limits the sludge mass that can be retained in the reactor.

\section{ACKNOWLEDGEMENTS}

The experimental investigation was carried out with financial support from agency of the Brazilian Government FINEP, through the BIOGAS project.

\section{REFERENCES}

ABNT (ASSOCIAC̄̃̃O BRASILEIRA DE NORMAS TÉCNICAS) (2011) NBR 12.209: Elaboração de projetos hidráulico-sanitários de estações de tratamento de esgotos sanitários. ABNT, Rio de Janeiro. 53 pp.

AIYUK S, FORREZ I, DE KEMPENEER L, VAN HAANDEL AC and VERSTRAETE W (2006) Anaerobic and complementary treatment of domestic sewage in regions with hot climates - A review. Bioresour. Technol. 97 2225-2241. https://doi.org/10.1016/j. biortech.2005.05.015

CHERNICHARO CAL, VAN LIER JB, NOYOLA A and BRESSANI RIBEIRO T (2015) Anaerobic sewage treatment: state of the art, constraints and challenges. Rev. Environ. Sci. Biotechnol. 1464914679. https://doi.org/10.1007/s11157-015-9377-3

COELHO ALSS, NASCIMENTO MBH, CAVALCATI PFF and HAANDEL AC (2003) The UASB reactor as an alternative for the septic tank for on-site sewage treatment accepted for publication. Water Sci. Technol. 48 (12) 659-664.

GHASIMI DS M, TAO Y, KREUK MK, ZANDVOORT MH and VAN LIER JB (2015) Microbial population dynamics during long-term sludge adaptation of thermophilic and mesophilic sequencing batch digesters treating sewage fine sieved fraction at varying organic loading rates. Biotechnol. Biofuels 8 (1) 355. https://doi.org/10.1186/ s13068-015-0355-3

GUJER W and ZEHNDER AJB (1983) Conversion processes in anaerobic digestion. Water Sci. Technol. 15 127-167.

IKUMI DS, HARDING TH and EKAMA GA (2014) Biodegradability of wastewater and activated sludge organics in anaerobic digestion. Water Res. 56 267-279. https://doi.org/10.1016/j.watres.2014.02.008

LEITÃO RC (2004) Robustness of UASB reactors treating sewage under tropical conditions. PhD thesis, Wageningen University.

LETTINGA G, DE MAN AWA, VAN DER LAST ARM, WIEGANT W, KNIPPENBERG K, FRIJNS J and VAN BUUREN JCL (1993) Anaerobic treatment of domestic sewage and wastewater. Water Sci. Technol. 27 67-73.

LEW B, LUSTING I, BELIAVSKI M, TARRE S and GREEN M (2011) An integrated UASB-sludge digester system for raw domestic wastewater treatment in temperate climates. Bioresour. Technol. 102 (7) 4921-4924. https://doi.org/10.1016/j.biortech.2011.01.030

LUOSTARINEN S, SANDERS W, ROELEVELD KK and ZEEMAN G (2007) Effect of temperature on anaerobic treatment of black water in UASB-septic tank systems. Bioresour. Technol. 98 (5) 980-986. https://doi.org/10.1016/j.biortech.2006.04.018 
MARAIS GVR and EKAMA GA (1976) The Activated Sludge Process Part I: Steady State Behaviour. Water SA 2 (4) 164-200.

SANTOS S L, CHAVES SRM and VAN HAANDEL C (2016) Influence of phase separator design on the performance of UASB reactors treating municipal wastewater. Water SA 42 (2) 176-182. https:// doi.org/10.4314/wsa.v42i2.01

VAN HAANDEL AC and LETTINGA G (1994) Anaerobic Sewage Treatment: A Practical Guide for Regions with a Hot Climate. John Wiley and Sons, Chichester, UK. 222 pp.

VAN LIER JB, MAHMOUD N and ZEEMAN G (2008) Anaerobic wastewater treatment. In: Biological Wastewater Treatment: Principles, Modelling and Design. IWA Publishing, London. 415-456.
VERSTRAETE W, TANGHE T, DE SMUL A and GROOTAERD H (1997) Anaerobic biotechnology for sustainable waste treatment. In: Sayler GS (ed.) Biotechnology in the Sustainable Environment. Plenum Press, New York. 343-359. https://doi. org/10.1007/978-1-4615-5395-3_30

VESILIND PA (1967) Theoretical considerations: design of prototype thickeners from batch settling tests. Water and Sewage Works 115 (7).

WENTZEL MC, EKAMA GA and SÖTEMANN SW (2006) Mass balance-based plant-wide wastewater treatment plant models Part 1: Biodegradability of wastewater organics under anaerobic conditions. Water SA 32 (3) 269-275. 